\title{
CHANGES IN THE POPULATION OF SOME FUNCTIONAL GROUPS OF RUMEN BACTERIA INCLUDING METHANOGENIC BACTERIA BY CHANGING THE RUMEN CILIATES IN CALVES
}

\author{
AKIO TAKENAKA* AND HISAO ITABASHI \\ National Institute of Animal Industry, Tsukuba Norindanchi, \\ P.O. Box 5, Ibaraki 305, Japan \\ (Received November 2, 1993; Accepted August 4, 1995)
}

\begin{abstract}
Twelve unfaunated male calves aged 5-8 months were inoculated with monogeneric protozoa (Epidinium ecaudatum, Eudiplodinium maggii or Entodinium. spp.) or mixed protozoa population. Thus, five groups of rumen protozoa population were established; Unf (unfaunated, protozoafree), Epi (Epidinium ecaudatum mono-faunated), Eud (Eudiplodinium maggii mono-faunated), Ent (Entodinium spp. mono-faunated), and Mix (mixed Ophryoscolecids protozoa faunated). The number of total viable bacteria in the rumen was significantly lower in the Epi, Eud and Mix groups than the Unf group. The population of amylolytic bacteria was significantly lower in the Epi group than the Unf group. That of pectinolytic bacteria was higher in the Ent group than the other faunated groups. The number of methanogenic bacteria was significantly higher in the Ent, Eud and Mix groups than Unf, however the Epi group had a lower value than the other faunated groups. The concentration of rumen ammonia-N peaked at $1 \mathrm{~h}$ after feeding and was significantly higher in the Mix group than in the other groups, and was the lowest in the Unf group. The concentration of rumen volatile fatty acids (VFAs) increased until $2 \mathrm{~h}$ after feeding. The values of the Unf group were lower than the other groups, but the differences were not significant. The molar proportion of acetate was lowest in the Mix group, highest in the Unf group and the other groups had values intermediate between these two groups. The proportion of butyrate and propionate was lowest in the Unf group.
\end{abstract}

Digestion in ruminants is characterized by rumen fermentation which is done by the rumen microbial population, constituted mainly of bacteria, ciliates (proto-

* Address reprint requests to: Dr. Akio Takenaka, National Institute of Animal Industry, Tsukuba Norindanchi, P.O. Box 5, Ibaraki 305, Japan. 
zoa) and fungi. The role of bacteria is satisfactorily known, but that of protozoa is not well established, in spite of the many studies performed to investigate the effect of protozoa on digestive physiology $(4,5,11,12,22,25,27)$. Rumen fermentation is not only affected by ruminal microorganisms but also by the quality and quantity of diet. A problem is that most reports have used mixed protozoa species. The use of mono-faunated animals is more informative because of the variety of metabolic activity between protozoa species. However, there are only a few reports which have used such mono-faunated animals.

Jouany et al. (13) noted that Polyplastron or Entodinium mono-faunated sheep had better organic matter and fiber digestion compared with Isotricha monofaunated animals. Matsumoto et al. (16) established Epidinium ecaudatum and Dasytricha ruminantium mono-faunated goats and conventionally faunated ones, and described that each group had different rumen fermentation properties. In our previous paper (24), we estimated that large types of Ophryoscolecids protozoa are more effective on rumen microflora and fermentation than small types of Ophryoscolecids or Isotrichids in calves. In this paper, we examined the effects of some species of Ophryoscolecids on microflora and fermentation in the rumen.

\section{MATERIALS AND METHODS}

Animals, feeding and sampling regimen. Ten Japanese black and two Holstein male calves aged 5-8 months were used in this experiment. The calves were isolated from their dams within a few days of birth in order to obtain unfaunated calves. Calves were inoculated with rumen fluid from other calves which had only one species of ciliate, Epidinium ecaudatum or Eudiplodinium maggii. In order to establish the Entodinium mono-faunated animals, the calves were fed with a diet containing calcium salts of caprylic acid and capric acid (50g each/day) (15). Thus, five groups of calves were established, which had five different types of microflora; i.e. Unf (unfaunated, $n=2$ ), Epi (Epidinium ecaudatum monofaunated, $n=3$ ), Eud (Eudiplodinium maggii mono-faunated, $n=4$, two of which were used for the Unf group previously), Ent (Entodinium spp. mono-faunated, $n=2$ ), and Mix (mixed Ophryoscolecids protozoa faunated, $n=3$ ). The population of ciliates in each group reached a plateau level approximately 2 or 3 weeks after inoculation; this is described in the discussion. All experiments were started at least two weeks after the animals were inoculated with the ciliates.

Each group was fed twice a day, at 9:00 and 16:00, with a 50\% Italian ryegrass hay-wafer and 50\% concentrate mixture (TDN: $82 \%$, CP: 15\%, urea: $1 \%$ ). The daily amount of diet offered was approximately $1.5 \%$ of body weight.

Samples of rumen fluid were collected through a stomach tube just before the morning feeding (time 0 ) and 1, 2, 4 and $6 \mathrm{~h}$ after feeding. The rumen fluid samples were immediately filtered through two layers of gauze and used for analysis.

Enumeration of protozoa. All the samples from the Unf group were checked under an optical microscope for the presence of protozoa. In order to count the 
protozoa, $1 \mathrm{ml}$ of rumen fluid was diluted with $4 \mathrm{ml}$ of saline containing $10 \%$ formalin and $0.03 \%$ methyl green. The protozoa in the samples were counted using a Fuchs-Rosenthal chamber and an optical microscope (18).

Enumeration of bacteria. The methods used to count the bacteria were essentially as described by Minato et al. (17). Ten fold serial dilutions of the rumen fluid sampled $6 \mathrm{~h}$ after feeding were made with the anaerobic dilution solution of Bryant and Burkey (2), to which agar was added at $0.1 \%(\mathrm{w} / \mathrm{v})$. Medium was inoculated with $0.2 \mathrm{ml}$ (except for methanogenic bacteria, $0.1 \mathrm{ml}$ ) from each of the appropriate dilutions.

Total viable counts of bacteria were made by the roll tube method with RGCMS agar medium (10). Colonies of the roll tubes were counted after one week at $39^{\circ} \mathrm{C}$, and the values were the average of at least three tubes at the appropriate dilution.

Viable counts of amylolytic, cellulolytic, xylanolytic, and pectinolytic bacteria were enumerated with a liquid medium (17). Amylolytic bacteria were counted with the basal medium supplemented with $0.1 \%$ soluble starch (Difco Laboratories, Detroit, MI, U.S.A.). Starch digestion was detected by the addition of an iodine solution to the medium after one week incubation at $39^{\circ} \mathrm{C}$. Xylanolytic and pectinolytic bacteria were counted with the basal medium supplemented with $0.5 \%$ xylan from oat spelts (Aldrich Chemical Company Inc., Milwaukee, WI, U.S.A.) or $0.5 \%$ pectin from citrus fruits (Sigma Chemical Company, St. Louis, MO, U.S.A.), respectively. The gas phase of the medium for xylanolytic and pectinolytic bacteria was $10 \% \mathrm{CO}_{2}-90 \% \mathrm{~N}_{2}$. The presence of xylanolytic or pectinolytic bacteria was determined by a $\mathrm{pH}$ decrease after one week of incubation at $39^{\circ} \mathrm{C}$.

Cellulolytic bacteria were counted with the basal medium supplemented with $0.12 \%$ yeast extract (Difco), a strip $(1 \times 3 \mathrm{~cm})$ of No. 2 filter paper (Toyo Roshi Kaisha, Ltd., Tokyo, Japan) and 0.02\% cellobiose (14). The gas phase was $100 \%$ $\mathrm{CO}_{2}$ and cellulose degradation was determined after two weeks of cultivation.

Methanogenic bacteria were counted with the liquid medium of Paynter and Hungate (21), supplemented with $0.2 \%$ sodium formate. The gas phase of the medium for methanogenic bacteria was $20 \% \mathrm{CO}_{2}-80 \% \mathrm{H}_{2}$, and was injected using a high-pressure $\mathrm{O}_{2}$-free gas injection device (1) (Sanshin Industrial Co., Ltd., Yokohama, Japan). Methanogenic bacteria were counted by the detection of methane in the gas phase after three weeks. Methane was determined by gas chromatography (Shimadzu, Kyoto, Japan, GC-R1A) with a molecular sieve column (5A, 60 to 80 mesh, Guild Corp., Bethel Park, PA, U.S.A.) operated at $70^{\circ} \mathrm{C}$.

In the liquid culture, the count of each functional group of bacteria was determined by the most probable number (MPN).

Analytical methods for rumen ammonia- $N$ and VFAs. Rumen ammonia-N were determined by the micro-diffusion method (24). The composition of VFAs were analyzed by gas chromatography (24) with a column of C-22 (60-80 mesh) adsorbed with $10 \% \mathrm{DEGA}+2 \% \mathrm{H}_{3} \mathrm{PO}_{4}$ operated at $150^{\circ} \mathrm{C}$. 
Statistical analyses. The results were analyzed statistically according to Duncan's multiple range test (7).

\section{RESULTS}

Changes in protozoal populations after feeding

There was no contamination with other species of protozoa in all the groups during the experimental period. Protozoal populations of Epidinium ecaudatum, Entodinium spp. and Eudiplodinium maggii mono-faunated groups are presented in Fig. 1. The protozoal population decreased after feeding, the lowest values appeared at $2 \mathrm{~h}$ after feeding except in the Epi group which had the lowest value at $4 \mathrm{~h}$ after feeding. However there were no significant differences between each of the values. The population of each protozoa in the Mix group was not significantly different from that of mono-faunated groups (data not shown).

\section{Viable counts of total bacteria}

The total viable number of bacteria is shown in Fig. 2. The Unf group had the
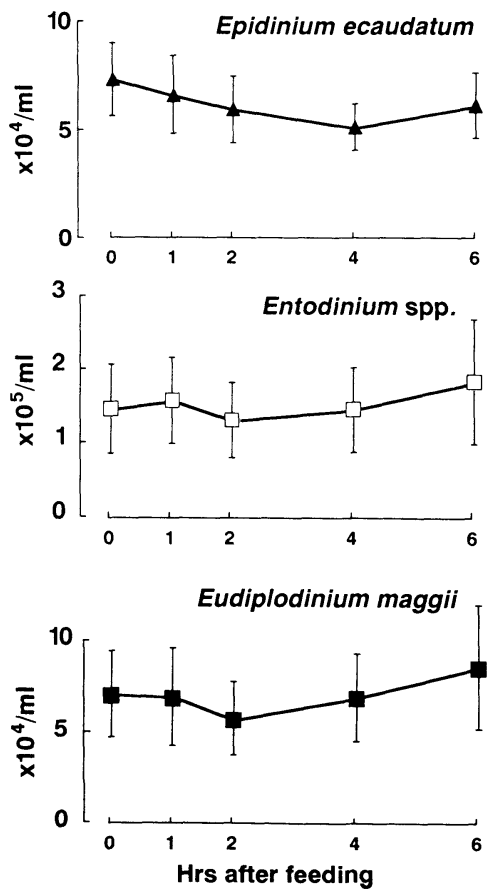

Fig. 1. Changes in protozoa number in rumen fluid of Epidinium ecaudatum mono-faunated (A), Entodinium spp. mono-faunated $(\square)$, and Eudiplodinium maggii mono-faunated ( $\boldsymbol{\square})$ calves after feeding.

Vertical bars show the standard errors of the mean. 
highest value $\left(9.12 \times 10^{8} / \mathrm{ml}\right)$. The Ent group had a relatively higher value $(5.37 \times$ $\left.10^{8} / \mathrm{ml}\right)$ among the faunated groups, while the Epi $\left(2.82 \times 10^{8} / \mathrm{ml}\right)$, Mix $(2.82 \times$ $\left.10^{8} / \mathrm{ml}\right)$ and Eud $\left(2.29 \times 10^{8} / \mathrm{ml}\right)$ groups had values significantly lower than the Unf group.

\section{Viable counts of the functional groups of bacteria}

The viable number of the following functional groups of bacteria are presented in Fig. 3. Amylolytic bacteria were predominant in each of the groups, except for the Ent group in which pectinolytic bacteria were predominant. The number of amylolytic bacteria was highest in the Unf group $\left(1.26 \times 10^{9} / \mathrm{ml}\right)$, followed by the Eud $\left(9.55 \times 10^{8} / \mathrm{ml}\right)$, Mix $\left(8.32 \times 10^{8} / \mathrm{ml}\right)$, Ent $\left(5.89 \times 10^{8} / \mathrm{ml}\right)$ and Epi groups $(2.57$ $\times 10^{8} / \mathrm{ml}$ ). The difference between the Unf and Epi groups was significant. The population of xylanolytic bacteria was also highest in the Unf group $\left(2.95 \times 10^{8} / \mathrm{ml}\right)$ followed by the Eud $\left(2.40 \times 10^{8} / \mathrm{ml}\right)$, Ent $\left(1.91 \times 10^{8} / \mathrm{ml}\right)$, Mix $\left(1.82 \times 10^{8} / \mathrm{ml}\right)$ and Epi groups $\left(1.05 \times 10^{8} / \mathrm{ml}\right)$. The population of pectinolytic bacteria was nearly the

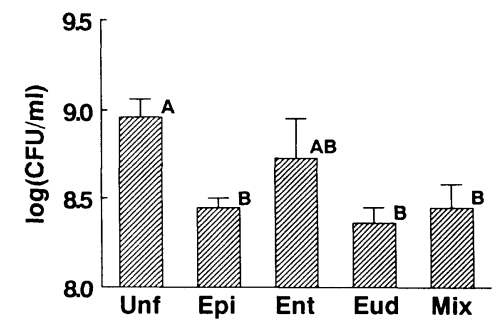

Fig. 2. Total number of viable ruminal bacteria in the different groups of calves. Rumen samples were taken $6 \mathrm{~h}$ after feeding. Values are the means of at least 3 different experiments. Unf, unfaunated; Epi, Epidinium ecaudatum mono-faunated; Ent, Entodinium spp. mono-faunated; Eud, Eudiplodinium maggii mono-faunated; Mix, mixed Ophryoscolecids protozoa faunated. Vertical bars indicate the standard errors of the mean. Values with different letters are significantly different $(p<0.05)$.

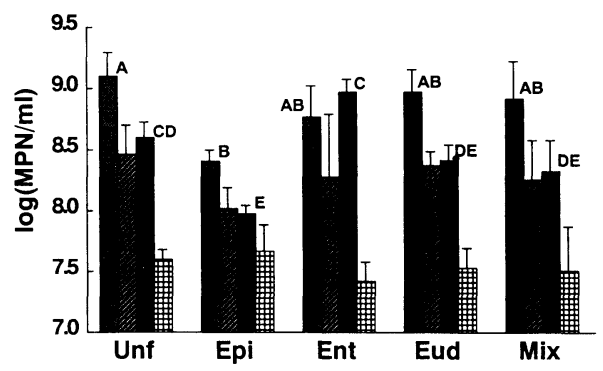

Fig. 3. Number of amylolytic bacteria (घ), cellulolytic bacteria (团), xylanolytic bacteria $(\mathbb{Z})$, and pectinolytic bacteria $(\mathbb{D})$ in the rumen fluid of the different groups of calves.

Values within the same category with different letters are significantly different $(p<0.05)$. For details, see Fig. 2 . 
same as that of xylanolytic bacteria in all groups, except for the Ent group which had a significantly higher number of pectinolytic bacteria $\left(9.55 \times 10^{8} / \mathrm{ml}\right)$ than the other faunated groups.

On the other hand, the number of cellulolytic bacteria was highest in the Epi group $\left(4.68 \times 10^{7} / \mathrm{ml}\right)$ followed by the Unf $\left(3.98 \times 10^{7} / \mathrm{ml}\right)$, Eud $\left(3.39 \times 10^{7} / \mathrm{ml}\right)$, Mix $\left(3.24 \times 10^{7} / \mathrm{ml}\right)$ and Ent groups $\left(2.63 \times 10^{7} / \mathrm{ml}\right)$ respectively, but the differences between each group were not significant.

\section{Viable counts of methanogenic bacteria}

The viable number of methanogenic bacteria in each group is presented in Fig. 4. The population of methanogenic bacteria was significantly higher in the Ent $\left(1.32 \times 10^{7} / \mathrm{ml}\right)$, Eud $\left(1.17 \times 10^{7} / \mathrm{ml}\right)$ and Mix groups $\left(1.23 \times 10^{7} / \mathrm{ml}\right)$ than in the Unf group $\left(1.12 \times 10^{6} / \mathrm{ml}\right)$. The population of methanogenic bacteria was also larger in the Epi group $\left(3.63 \times 10^{6} / \mathrm{ml}\right)$ than in the Unf group, but the difference was not significant.

Changes in the concentration of rumen ammonia- $N$ and the concentration of rumen $V F A$ after feeding

The concentration of rumen ammonia- $\mathrm{N}$ peaked $1 \mathrm{~h}$ after feeding in all groups and was significantly higher in the Mix group than the other groups (Fig. 5). The Unf group had the lowest values at all times. The values of the Unf group were significantly lower than those of the Eud group at 1, 2, and $4 \mathrm{~h}$ after feeding.

The concentration of rumen VFA increased until $2 \mathrm{~h}$ after feeding. The VFA values in the Unf group were lower than the faunated groups. There were no significant differences between faunated groups (Fig. 6).

\section{Changes in the molar proportion of rumen VFAs after feeding}

The molar proportion of acetate, propionate and butyrate are presented in Fig. 7. The values of acetate were significantly higher in the Unf group than the Mix group, and those of butyrate were significantly higher in the Mix group than the Unf group at 0,4 , and $6 \mathrm{~h}$ after feeding; the other groups had intermediate values. The molar proportion of propionate was significantly higher in the Ent group at $1 \mathrm{~h}$

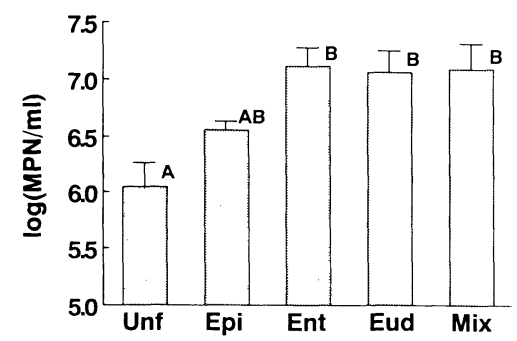

Fig. 4. Number of methanogenic bacteria in the rumen fluid of the different groups of calves. For details, see Fig. 2.

Values with different letters are significantly different $(p<0.05)$. 


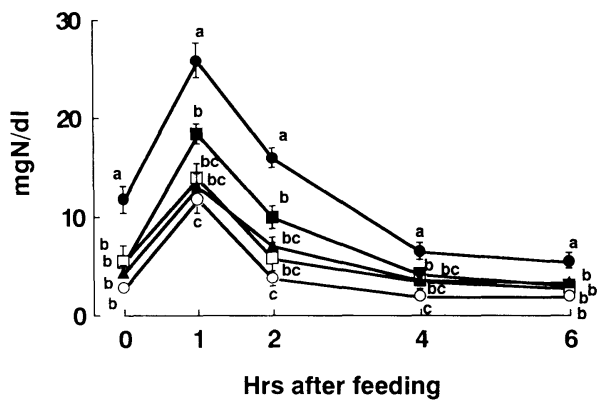

Fig. 5. Changes in concentration of ammonia-N in the rumen fluid of calves after feeding.

Unf $(\bigcirc)$, Epi $(\Delta)$, Ent $(\square)$, Eud $(\square)$, and Mix $(\bullet)$ group. Values are the mean of at least 3 experiments. Vertical bars indicate the standard errors of the mean. Values in the same time with different letters are significantly different $(p<0.01)$.

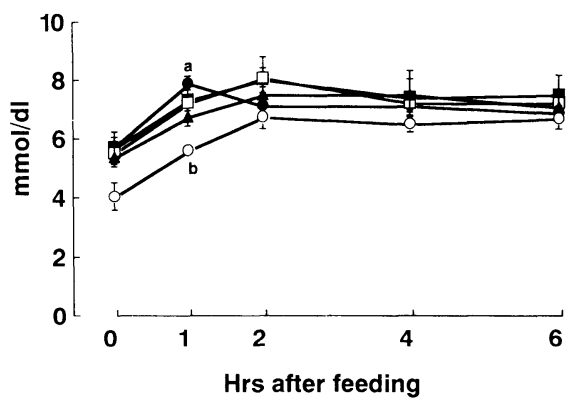

Fig. 6. Changes in concentration of VFA in the rumen fluid of calves after feeding.

The symbols used are the same as those in Fig. 5. Vertical bars indicate the standard errors of the mean. Values in the same time with different letters are significantly different $(p<0.01)$.

after feeding and in the Eud group at $2 \mathrm{~h}$ after feeding than in the Unf group.

The molar proportion of minor VFAs are presented in Fig. 7. The Mix group had significantly higher values than the other groups before feeding. On the other hand, the lowest value for each minor VFA was in a different group for each acid, i.e. valerate in the Epi group, iso-butyrate in the Ent group and iso-valerate in the Eud group, respectively. However, the differences were not significant.

\section{DISCUSSION}

Previous reports (24) described that the population of Ophryoscolecids was decreased and that of Isotrichids peaked after feeding. This is due to the great mobility of the Isotrichids relative to the Ophryoscolecids. The decrease in the population of Ophryoscolecids after feeding was due to the effects of dilution 

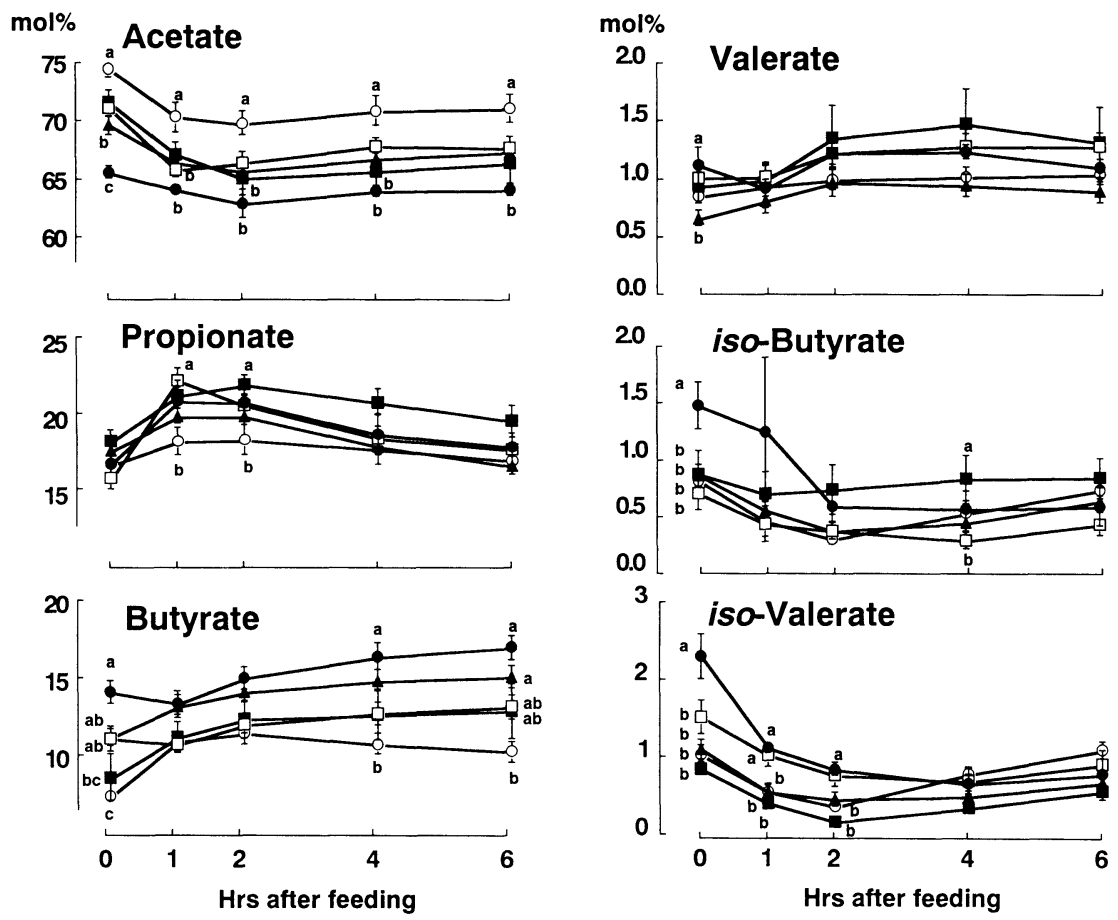

Fig. 7. Changes in molar proportion of VFAs in the rumen fluid of calves after feeding.

The symbols used are the same as those of Fig. 5. Vertical bars indicate the standard errors of the mean. Values in the same time with different letters are significantly different $(p<0.01)$.

because of their poor motility. There were no differences between the monofaunated and poly-faunated animals in the population of Ophryoscolecids. The population of protozoa in mono-faunated animals ranged in the order of $10^{5}-10^{6} / \mathrm{ml}$ for small Entodinium spp. and $10^{4}-10^{5} / \mathrm{ml}$ for large Epidinium ecaudatum and Eudiplodinium maggii, it seems the biomass of protozoa in each rumen was approximately the same.

The metabolic differences between Isotrichids and Ophryoscolecids are well known $(13,25,29)$. Isotrichids prefer to use soluble carbohydrates, while Ophryoscolecids can degrade insoluble materials because they can engulf particles.

It is difficult to explain the differences between small types and large types of Ophryoscolecids. These two types of protozoa have different metabolic characteristics as well as different sizes. Jouany et al. (13) reported that large types of Ophryoscolecids such as Polyplastron are the most effective for cellulose digestion. Ushida et al. (26) described how cellulose digestion was improved by Entodinium inoculation to defaunated sheep, although xylan digestion was not improved until continuous inoculation of such large types of Ophryoscolecids as Diplodinium and 
Polyplastron to the sheep. It is most likely that the effect of Entodinium is to improve the ruminal environment for cellulolytic bacteria by consuming lactate because most cellulolytic bacteria are acid sensitive. So, the effect of Entodinium is probably indirect. The positive effect of Epidinium for cellulolytic bacteria is also likely to be indirect.

Many researchers $(8,20,29)$ have reported that the rumen bacterial population is higher in unfaunated or defaunated animals than in faunated ones. There are two main reasons for the decrease in bacterial number when protozoa are present. First, the number of bacteria decreases because protozoa engulf them directly. Second there is competition for nutrients between bacteria and protozoa. The total number of rumen bacteria decreased with large Epidinium and Eudiplodinium inoculation rather than small Entodinium inoculation (Fig. 2). We estimated that direct engulfment is more effective in reducing the bacterial number in these cases.

It is a remarkable result that pectinolytic bacteria were predominant in the Ent group, suggesting the specific effect of Entodinium on pectinolytic bacteria. The viable number of cellulolytic bacteria was relatively higher in the Epi group as described in a previous paper (24). The population of methanogenic bacteria was significantly higher in all the faunated groups than in unfaunated animals, except for the Epi group where the difference was not significant (Fig. 4). These findings were also noted by Vogels et al. (28), who reported that entodiniomorphid ciliates which were regularly found in healthy cows were attached by methanogenic bacteria. They also described that the association rates in Epidinium species was relatively lower than the other Ophryoscolecid groups.

The rumen ammonia concentration was higher in the Eud group than in the Epi and Eud groups (Fig. 5). Since ammonia in the rumen is mainly produced from feed proteins (19) and it has been reported that some species of ciliates have proteases $(6,9)$, Eudiplodinium maggii might have stronger proteases compared with the other species. A clear result of the present study was the stimulation of ammonium production in the Mix group, this is probably due to the many types of proteases and peptidases which were produced by the mixed protozoa.

The rumen VFA concentration was higher in the faunated groups than the Unf group. This might be due to the increased digestion of fiber by the faunation as suggested by Jouany et al. (13). The effect of protozoa on the molar proportion of VFAs in the rumen are not coincident among different researchers (29). In this paper, it is clear that the molar proportion of acetate was decreased and that of butyrate was increased by the inoculation of protozoa, especially when mixed protozoa were inoculated. This result is similar to that reported in our previous paper (24). There is general accordance regarding the cause of the increased proportion of butyrate by the faunation; it is ascribed to the fact that most protozoa can produce butyrate actively (27). However, many reports described increased acetate and decreased propionate by faunation (12). VFA composition is very important for the rumen bacterial population because certain types of ruminal 
bacteria were controlled by $\operatorname{VFA}(3,23)$. More studies are needed to resolve discrepancies on VFA proportion among many researches.

This work was supported in a part by a Grant-in-Aid (Bio-Cosmos Program) from the Ministry of Agriculture, Forestry and Fisheries (BCP 94-II-B-1).

\section{REFERENCES}

1) Balch, W. E., Fox, G. E., Magrum, L. J., Woese, C. R., and Wolfe, R. S., Methanogens: Reevaluation of a unique biological group. Microbiol. Rev., 43, 260-296 (1979).

2) Bryant, M. P. and Burkey, L. A., Cultural methods and some characteristics of some of the more numerous group of bacteria in the bovine rumen. J. Dairy Sci., 36, 205-217 (1953).

3) Chambers, P. G. and Lysons, R. J., The inhibitory effect of bovine rumen fluid on Salmonella typhimurium. Res. Vet. Sci., 26, 273-276 (1979).

4) Clarke, R. T. J., Protozoa in the rumen ecosystem. In Microbial Ecology of the Gut, ed. by Clark, R. T. J. and Buachop, T., Academic Press, London (1977), p. 251-275.

5) Coleman, G. S., Rumen ciliate protozoa. Adv. Parasitol., 18, 121-173 (1980).

6) Coleman, G. S., Hydrolysis of Fraction 1 leaf protein and casein by rumen entodiniomorphid protozoa. J. Appl. Bacteriol., 55, 111-118 (1983).

7) Duncan, D. B., Multiple range and multiple F tests. Biometrics, 11, 1-42 (1955).

8) Eadie, J. M. and Hobson, P. N., Effect of the presence or absence of rumen ciliate protozoa on the total rumen bacterial count in lambs. Nature, 193, 503-504 (1962).

9) Forsberg, C. W., Lovelock, L. K., Krumholtz, L., and Buchanan-Smith, J. G., Protease activities of rumen protozoa. Appl. Environ. Microbiol., 47, 101-110 (1984).

10) Hungate, R. E., A roll tube method for cultivation of strict anaerobes. In Method in Microbiology, Vol. 3B, ed. by Norris, J. R. and Ribbons, D. W., Academic Press, New York (1969), p. 118-132.

11) Itabashi, H., Kobayashi, T., Takenaka, A., and Matsumoto, M., Effect of protozoa on nutritional characteristics of ruminant. In The Rumen Ecosystem, ed. by Hoshino, S., Onodera, R., Minato, H., and Itabashi, H., Japan Scientific Societies Press/Springer Verlag, Tokyo (1990), p. 169-176.

12) Jouany, J. P., Demeyer, D. I., and Grain, J., Effect of defaunating the rumen. Anim. Feed Sci. Technol., 21, 229-265 (1988).

13) Jouany, J. P., Zainab, B., Senaud, J., Groliere, C. A., Grain, J., and Thivend, P., Role of the rumen ciliate protozoa Polyplastron multivesiculatum, Entodinium sp. and Isotricha prostoma in the digestion of a mixed diet in sheep. Reprod. Nutr. Dev., 21, 871-884 (1981).

14) Mann, S. O., An improved method for determining cellulolytic activity in anaerobic bacteria. $J$. Appl. Bacteriol., 31, 241-244 (1968).

15) Matsumoto, M., Kobayashi, T., Takenaka, A., and Itabashi, H., Defaunation effects of mediumchain fatty acids and their derivatives on goat rumen protozoa. J. Gen. Appl. Microbiol., 37, 439-445 (1991).

16) Matsumoto, M., Takenaka, A., Kobayashi, T., and Itabashi, H., The effects of Epidinium caudatum or Dasytricha ruminantium on the rumen fermentation and nitrogen metabolism in goats. Asian-Aust. J. Anim. Sci., 2, 483-484 (1989).

17) Minato, H., Ishizaki, S., Adachi, Y., and Mitsumori, M., Effect on rumen microbial populations of ammonia treatment of rice straw forage for steers. J. Gen. Appl. Microbiol., 35, 113-124 (1989).

18) Ogimoto, K. and Imai, S., Atlas of Rumen Microbiology, Japan Scientific Societies Press, Tokyo (1981), p. 157-167.

19) Onodera, R. and Kandatsu, M., Amino acids and protein metabolism of rumen ciliate protozoa. IV. Metabolism of casein. Jpn. J. Zootech. Sci., 41, 307-313 (1970).

20) Orpin, C. G. and Letcher, A. J., Effect of absence of ciliate protozoa on rumen fluid volume, flow rate and bacterial populations in sheep. Anim. Feed Sci. Technol., 10, 145-153 (1983/84). 
21) Paynter, M. J. B. and Hungate, R. E., Characterization of Methanobacterium mobilis, sp. n., isolated from the bovine rumen. J. Bacteriol., 95, 1943-1951 (1968).

22) Rowe, J. B., Davies, A., and Broome, A. W. J., Quantitative effects of defaunation on rumen fermentation and digestion in sheep. Br. J. Nutr., 54, 105-119 (1985).

23) Stewart, C. S., Some effects of phosphate and volatile fatty acid salts on the growth of rumen bacteria. J. Gen. Microbiol., 89, 319-326 (1975).

24) Takenaka, A., Matsumoto, M., Kobayashi, T., and Itabashi, H., The effects of the rumen ciliates Dasytricha, Epidinium and Entodinium on rumen bacterial concentrations and fermentation in calves. Anim. Sci. Technol. (Jpn.), 62, 368-374 (1991).

25) Ushida, K., Jouany, J. P., and Demeyer, D., Effect of presence or absence of rumen protozoa on the efficiency of utilization of concentrate and fibrous feeds. In Physiological Aspects of Digestion and Metabolism in Ruminants, ed. by Tsuda, T., Sasaki, Y., and Kawashima, R., Academic Press, San Diego (1991), p. 625-654.

26) Ushida, K., Kaneko, T., and Kojima, Y., Effect of presence of large Entodiniomorphid protozoa on the rumen bacterial flora, fauna composition of small Entodinia and in vitro cellulolysis and xylanolysis. Jpn. J. Zootech. Sci., 58, 893-902 (1987).

27) Veira, D. M., The role of ciliate protozoa in nutrition of the ruminant. J. Anim. Sci., 63, 15471560 (1986).

28) Vogels, G. D., Hoppe, W. F., and Stumm, C. K., Association of methanogenic bacteria with rumen ciliates. Appl. Environ. Microbiol., 40, 608-612 (1980).

29) Williams, A. G. and Coleman, G. S., The rumen protozoa. In The Rumen Microbial Ecosystem, ed. by Hobson, P. N., Elsevier Sci. Publishers, London/New York (1988), p. 77-128. 